\title{
The effect of pregnancy on the expression of uterine oxytocin, oestrogen and progesterone receptors during early pregnancy in the cow
}

\author{
R S Robinson ${ }^{1}$, G E Mann ${ }^{2}$, G E Lamming ${ }^{2}$ and D C Wathes ${ }^{1}$ \\ ${ }^{1}$ Department of Veterinary Basic Sciences, Royal Veterinary College, Hawkshead Road, Potters Bar, Hertfordshire EN6 1NB, UK \\ ${ }^{2}$ Division of Animal Physiology, School of Biological Sciences, University of Nottingham, Sutton Bonnington, Loughborough, Leicestershire, LE12 5RD, UK \\ (Requests for offprints should be addressed to D C Wathes)
}

\begin{abstract}
The expression of oxytocin receptor (OTR) in the uterine endometrium plays an important role in the initiation of luteolysis. During early pregnancy, the conceptus secretes interferon tau (IFN $\tau$ ) which inhibits OTR up-regulation and luteolysis. In this study, uterine horn cross sections were collected on day 16 from 15 pregnant cows (PREG), 9 uninseminated controls and 5 inseminated cows with no embryo present. The latter two groups had similar results and were combined to form a single non-pregnant (NP) group. The animals were given an oxytocin challenge shortly before tissue collection to assess prostaglandin $\mathrm{F}_{2 \alpha}$ $\left(\mathrm{PGF}_{2 \alpha}\right)$ release through the measurement of the metabolite 13,14-dihydro-15-keto $\mathrm{PGF}_{2 \alpha}$ (PGFM). The mRNAs for OTR, oestrogen receptor (ER) and progesterone receptor (PR) were localised by in situ hybridisation. The results were quantified by optical density (OD) measurements from autoradiographs using image analysis. OTR protein was measured by autoradiography with iodinated oxytocin antagonist and ER and PR protein was detected by immunocytochemistry. The release of PGFM after the oxytocin challenge was significantly higher in the
\end{abstract}

14 NP cows $(187 \% \pm 15 \%)$ compared with the PREG group $(131 \% \pm 11 \%) \quad(P<0 \cdot 01)$. Low concentrations of OTR mRNA were localised to the luminal epithelium (LE) in 6 out of the $14 \mathrm{NP}$ cows, of which 2 also expressed OTR protein, while OTR mRNA and protein were undetectable in all the pregnant animals. These results indicated that the sampling time coincided with the onset of the luteolytic mechanism in the NP cows. On day 16 ER mRNA was detectable in both the LE and glands of both PREG and NP animals. There were no differences in either ER mRNA or protein between NP and PREG samples. PR mRNA was moderately expressed in the caruncular stroma, with lower levels in the dense caruncular-like stroma and glands. There were no differences between PREG and NP animals. The expression of PR mRNA and protein in the deep glands was variable between animals. These results suggested that, in cows, the presence of an embryo suppressed the expression of OTR, but had no effect on the expression of the transcriptionally regulated ER on day 16.

Journal of Endocrinology (1999) 160, 21-33

\section{Introduction}

The up-regulation of endometrial oxytocin receptors plays an important role in the initiation of luteolysis in ruminants (McCracken et al. 1984). Oxytocin secreted from the corpus luteum (Wathes \& Denning-Kendall 1992) and probably also from the neurohypophysis, binds to endometrial oxytocin receptors, initiating prostaglandin $\mathrm{F}_{2 \alpha}$ $\left(\mathrm{PGF}_{2 \alpha}\right)$ pulsatile secretion and consequently luteal regression (Flint \& Sheldrick 1983). The oxytocin receptor gene is temporally and spatially regulated in the ovine endometrium throughout the oestrous cycle, with receptors first appearing in the luminal epithelium (LE) on day 14 in sheep, increasing to a peak at oestrus (day 0) when receptors also develop on the glandular epithelium and caruncular stroma (Wathes \& Hamon 1993, Stevenson et al. 1994). In cattle, the initial rise in oxytocin receptors preceding luteolysis is on day 15-17 (Jenner et al. 1991, Mann \& Lamming 1994).

During early pregnancy, the up-regulation of oxytocin receptors and consequently luteolysis is inhibited by secretion of interferon tau (IFN $\tau$ ) from the trophodectoderm from days 12-25 in cattle (Farin et al. 1990) and from days 10-21 in sheep (Bazer 1989). IFN $\tau$ suppresses oxytocin receptor expression at the transcription level in sheep (Spencer et al. 1995a). In unilaterally pregnant ewes, in which the uterus had previously been transected, oxytocin receptor suppression occurred in the pregnant horn only, suggesting that IFN $\tau$ action is local rather than systemic (Lamming et al. 1995). IFN $\tau$ action is also transient, with early pregnant endometrium becoming responsive to oxytocin after 
only $3 \mathrm{~h}$ in culture in the absence of IFN $\tau$ (Silvia \& Raw 1993).

In the non-pregnant cycle, both the timing of endometrial oxytocin receptor development and responsiveness of the receptors to oxytocin in terms of $\mathrm{PGF}_{2 \alpha}$ release are influenced by the steroid hormones oestrogen and progesterone, presumably acting through their respective endometrial receptors. Oestradiol affects the magnitude, timing and pattern of $\mathrm{PGF}_{2 \alpha}$ pulses in response to oxytocin (Beard et al. 1994). The concentration of oestrogen receptors in the endometrium is highest at oestrus (Wathes \& Hamon 1993). Oestradiol administration in mid cycle raised caruncular endometrial oxytocin receptor concentrations after $12 \mathrm{~h}$ and initiated luteolysis (Hixon \& Flint 1987). Oestradiol also up-regulates expression of its own receptor (Wathes et al. 1996b, Ing \& Tornesi 1997). Conversely, progesterone has an inhibitory action on oxytocin receptor gene expression during the early and mid-luteal phase of the oestrous cycle (Wathes \& Hamon 1993). However, after 12 days of continuous exposure to progesterone in sheep, the progesterone block to oxytocin receptor up-regulation was lost (Vallet et al. 1990, Wathes et al. 1996b).

During the early and mid-luteal phases, oestrogen receptor expression is suppressed in the endometrium except in the deep glands, presumably by an inhibitory action of rising progesterone levels (Wathes \& Hamon 1993, Spencer \& Bazer 1995). At luteolysis in sheep, oestrogen receptors are again up-regulated, although it is uncertain whether this begins before or after the increase in oxytocin receptors in the luminal epithelium (Cherny et al. 1991, Wathes \& Hamon 1993). This rise in oestrogen receptor concentrations does not occur in pregnant ewes. In unilaterally pregnant ewes on day 16, there is an increase in oestrogen receptors in the non-pregnant horn only, suggesting a local suppressive effect in the pregnant horn (Lamming et al. 1995). Intrauterine infusion of recombinant ovine IFN $\tau$ (roIFN $\tau$ ) from day 10 to day 14 in cyclic sheep decreased endometrial oestrogen receptor mRNA and protein expression in comparison with control animals (Spencer et al. 1995a). Furthermore, roIFN $\tau$ was also able to suppress increases in both oestrogen receptor mRNA and oxytocin receptor protein in the luminal epithelium in response to oestradiol administered on day 12 (Spencer et al. 1995b). Based on these observations it has been hypothesised that IFN $\tau$ inhibits oxytocin receptor up-regulation by inhibiting a preceding rise in oestrogen receptor expression (Spencer \& Bazer 1995).

This hypothesis is derived from observations based mainly on the ewe. There is, however, a further interest in understanding the mechanisms associated with maternal recognition of pregnancy in the cow, due to the financial implications of the high incidence of early embryo loss in this species (Peters 1996). The aim of the experiment reported here was, therefore, to compare the pattern of oxytocin, oestrogen and progesterone receptor expression in the pregnant and non-pregnant bovine uterus on day 16. This stage was chosen to catch animals at the onset of luteolysis and before the divergence in progesterone levels in pregnant and non-pregnant animals, which normally occurs on day 17 (Mann et al. 1996). Receptor mRNA localisation was performed by in situ hybridisation, oxytocin receptor protein was identified by autoradiography and steroid receptor protein by immunocytochemistry.

\section{Materials and Methods}

All chemicals were from either BDH (Upminster, Essex, UK) or Sigma Chemicals (Poole, Dorset, UK) unless otherwise stated.

\section{Animals}

Twenty-nine barren Friesian/Holstein cows at the end of lactation were synchronised with two injections of estrumate $\left(\mathrm{PGF}_{2 \alpha}\right.$ analogue, Coopers Animal Health, Crewe, Cheshire, UK) administered 12 days apart. The cows were then either doubly inseminated 72 or $96 \mathrm{~h}$ post second prostaglandin injection or left as controls. Blood samples were collected from the jugular vein daily for progesterone and oestradiol analysis (Mann et al. 1996). To monitor the strength of development of a luteolytic mechanism, cows were injected on day 16 with a single i.v. bolus of $50 \mathrm{IU}$ oxytocin (Hoechst UK Ltd, Walton Manor, Milton Keynes, Bucks, UK) in $5 \mathrm{ml}$ saline, flushed in with a further $5 \mathrm{ml}$ saline. Plasma concentrations of 13,14 dihydro-15-keto $\mathrm{PGF}_{2 \alpha}$ (PGFM), the principal metabolite of $\mathrm{PGF}_{2 \alpha}$, were measured in blood samples collected at 20-min intervals for $1 \mathrm{~h}$ before the oxytocin injection and then at $10-$ min intervals for $1 \mathrm{~h}$ after the challenge. All samples were collected in heparinized tubes, centrifuged at $1500 \mathrm{~g}$ for $10 \mathrm{~min}$ and plasma stored at $-20{ }^{\circ} \mathrm{C}$. The cows were slaughtered on day 16 and the uteri were removed and flushed for embryos. If no embryo was found in the inseminated animals then the flushing procedure was repeated as a check. Uterine cross-sections, approximately $3 \mathrm{~cm}$ in length, were taken and frozen in isopentane in liquid nitrogen and stored at $-80{ }^{\circ} \mathrm{C}$ for subsequent analysis. In the pregnant animals the cross-sections were taken from the horn with the embryo present.

\section{Radioimmunoassays for PGFM, progesterone and oestradiol}

Plasma samples were assayed for PGFM after extraction with acidified diethyl ether by radioimmunoassay (Kaker et al. 1984). Sensitivity of the assay was $15 \mathrm{pg} / \mathrm{ml}$ and the intra- and inter-assay coefficients of variation were $<15 \%$ and $12 \cdot 1 \%$ respectively. Progesterone was measured in plasma samples after extraction with petroleum ether by radioimmunoassay (Haresign et al. 1975) with antisera obtained from Dr B J A Furr. The sensitivity of the assay 
was $0.3 \mathrm{ng} / \mathrm{ml}$ and the intra- and interassay coefficients of variance were $<10 \%$ and $13 \cdot 8 \%$ respectively. Oestradiol was measured in plasma using a modified radioimmunoassay kit (Serono Diagnostics, Woking, Surrey, UK) (Mann et al. 1995). The sensitivity of the assay was $0.5 \mathrm{pg} / \mathrm{ml}$ and the intra- and interassay coefficients of variance were $<10 \%$ and $11 \cdot 3 \%$ respectively.

\section{Oligonucleotide probes}

All probes used were single-stranded oligonucleotides 45 bases in length (Brabaham Institute, Cambridge, UK). Sense probes were always included as negative controls and any signal from these was regarded as non-specific. The oxytocin receptor (OTR) sense sequence corresponded to the bovine oxytocin receptor gene bases 3504 to 3548: 5' TTCGTGCAGATGTGGAGTGT CTGGG ATGCCGATGCGCCCAAGGAA $3^{\prime}$ and was taken from transmembrane VI region (Bathgate et al. 1995). The oestrogen receptor (ER) sense sequence corresponded to the ovine ER $\alpha$ gene bases 564 to 608: 5' GGCTATGCG GTGCGCGAAGCCGGCCCTCCCGCCTACTACA GGCCA 3' from domain B (Madigou et al. 1996). The progesterone receptor $(\mathrm{PR})$ sense sequence corresponded to the ovine progesterone receptor gene bases 531-575: 5' CTTCTCTCAGTGGTCAAGTGGTCTAAGTCA CTGCCAGGTTTTCGG 3' (Madigou et al. 1995). The full corresponding sequence for the bovine ER and PR genes has not yet been published, but these regions are highly conserved between species for which the sequence is known.

\section{Localisation of $m R N A$ by in situ hybridisation}

The method was based upon that previously described by Stevenson et al. (1994). Sections $(10 \mu \mathrm{m})$ were cut and thaw-mounted onto $1 \mathrm{mg} / \mathrm{ml}$ poly-L-lysine $\left(\mathrm{M}_{\mathrm{r}}>300000\right)$ coated glass slides. The sections were fixed in $4 \%(\mathrm{w} / \mathrm{v})$ paraformaldehyde in $0.01 \mathrm{M}$ PBS, $\mathrm{pH} 7 \cdot 0$ for $5 \mathrm{~min}$ at room temperature and then washed three times with $0 \cdot 01 \mathrm{M}$ PBS. The slides were sequentially dehydrated in ethanol and stored at $4{ }^{\circ} \mathrm{C}$ in $95 \%$ ethanol. Oligonucleotide probe $(5 \mathrm{ng})$ was end-labelled with ${ }^{35} \mathrm{~S}$-dATP (ICN Chemicals, Thame, Oxfordshire, UK) using deoxynucleotidyl transferase (Pharmacia Biotech, St Albans, Herts, UK) at $34{ }^{\circ} \mathrm{C}$ for $1 \mathrm{~h}$. The labelled probe was diluted to a final concentration of 1100000 c.p.m. $/ \mathrm{ml}$ in hybridisation buffer $(50 \%(\mathrm{v} / \mathrm{v})$ deionised formamide, $4 \times \mathrm{SSC}, \quad 25 \mathrm{mM}$ sodium phosphate, $1 \mathrm{mM}$ sodium pyrophosphate, $5 \times$ Denhardt's solution, $0.2 \mathrm{mg} / \mathrm{ml}$ denatured salmon sperm DNA, $120 \mu \mathrm{g} / \mathrm{ml}$ sodium heparin, $100 \mu \mathrm{g} / \mathrm{ml}$ polyadenylic acid and $100 \mathrm{mg} / \mathrm{ml}$ dextran sulphate) and $100 \mu \mathrm{l}$ added to each section. The sections were incubated in a humidified box at $42.5{ }^{\circ} \mathrm{C}$ overnight. The slides were washed in $1 \times \mathrm{SSC}, 0 \cdot 2 \%$ $(\mathrm{w} / \mathrm{v})$ sodium thiosulphate at room temperature for
$30 \mathrm{~min}$, then in fresh $1 \times \mathrm{SSC}, 0 \cdot 2 \%(\mathrm{w} / \mathrm{v})$ sodium thiosulphate at $57.5{ }^{\circ} \mathrm{C}$ for $60 \mathrm{~min}$. The sections were washed for $1 \mathrm{~min}$ in $1 \times \mathrm{SSC}, 0 \cdot 1 \times \mathrm{SSC}, 75 \%$ ethanol and 95\% ethanol and air dried. The slides were exposed to $\beta$-max hyperfilm (Amersham International, Aylesbury, Bucks, UK) for 14 days (oxytocin and progesterone receptor) or 24 days (oestrogen receptor).

\section{Photographic emulsions}

Slides previously exposed to X-ray film were coated with photographic emulsion LM1 (Amersham International) as instructed and left at $4{ }^{\circ} \mathrm{C}$ for 3 weeks (oxytocin and progesterone receptor) or 5 weeks (oestrogen receptor). The slides were developed in $20 \%$ phenisol, fixed in $1.9 \mathrm{M}$ sodium thiosulphate and counterstained with haematoxylin and eosin to confirm cellular localisation of the radioactive signal.

\section{Optical density measurements}

Optical density (OD) measurements were made using a Seescan image analysis system (Seescan plc, Cambridge, UK) as described by Stevenson et al. (1994). In brief, autoradiographs were projected onto a computer screen, the region of interest was encircled and the OD reading was measured. The background OD, from a blank autoradiograph, was first automatically subtracted. The OD value for the sense section was subtracted from the corresponding antisense section. Readings were obtained from two sections per cow and a mean value of specific hybridisation for each animal was then calculated. The limit of detection was taken as an OD value of 0.01.

\section{Autoradiographical localisation of oxytocin receptor}

The localisation of the oxytocin binding sites was determined by autoradiography using iodinated oxytocin receptor antagonist $\mathrm{d}\left(\mathrm{CH}_{2}\right)_{5}\left[\mathrm{Tyr}(\mathrm{Me})^{2}, \mathrm{Thr}^{4}, \mathrm{Tyr}-\mathrm{NH}_{2}{ }^{9}\right]-$ vasotocin $\left({ }^{125}\right.$ I-OTA) (kindly supplied by Dr M Manning, Medical College of Ohio, OH, USA) as previously described (Ayad et al. 1991). Sections $(20 \mu \mathrm{m})$ were cut and thaw-mounted onto chrome alum-gelatin coated slides. Endogenous bound oxytocin was removed by washing the slides twice in ice-cold $100 \mathrm{mM}$ sodium phosphate, $\mathrm{pH} 7 \cdot 4$ buffer containing $0 \cdot 1 \%(\mathrm{w} / \mathrm{v})$ BSA for $15 \mathrm{~min}$. The sections were incubated with OTA buffer $(100 \mathrm{mM}$ sodium phosphate, $\mathrm{pH} 7 \cdot 4,10 \mathrm{nM} \mathrm{MgCl}, 0 \cdot 1 \%(\mathrm{w} / \mathrm{v})$ BSA) containing $1.25 \times 10^{6}$ c.p.m. $/ \mathrm{ml}^{125}$ I-OTA for $1 \mathrm{~h}$ at room temperature. The non-specific binding was determined by incubating control slides with OTA buffer containing ${ }^{125} \mathrm{I}-\mathrm{OTA}$ and $10 \mu \mathrm{g} / \mathrm{ml}$ oxytocin (Bachem, Saffron Walden, Essex, UK). The slides were then washed in ice-cold OTA buffer for $3 \times 1 \mathrm{~min}$ and then dipped into ice-cold distilled water. The slides were dried and exposed to $\beta$-max hyperfilm (Amersham International) for $48 \mathrm{~h}$. 
Immunocytochemical localisation of oestrogen and progesterone receptor

The localisation of the oestrogen and progesterone receptors was based on the method previously described by Wathes \& Hamon (1993). Sections (6 $\mu \mathrm{m})$ were cut and thaw-mounted onto 3-aminopropylsilane (APES) coated slides. The sections were fixed in $3 \cdot 7 \%(\mathrm{v} / \mathrm{v})$ formaldehyde in $0.01 \mathrm{M}$ phosphate buffered saline (PBS) at room temperature for $10 \mathrm{~min}$ and then washed in $0.01 \mathrm{M} \mathrm{PBS}, \mathrm{pH}$ $7 \cdot 3$ at $4{ }^{\circ} \mathrm{C}$. The sections were further fixed in acetone at room temperature for $1 \mathrm{~min}$ and endogenous peroxidase blocked by incubating in methanol for $1 \mathrm{~min}$. The sections were washed twice at room temperature in $0 \cdot 01 \mathrm{M} \mathrm{PBS}$ for $5 \mathrm{~min}$. Each section was incubated with $3 \%(\mathrm{v} / \mathrm{v})$ normal rabbit serum in a humidified box for $10 \mathrm{~min}$ at room temperature. The sections were then incubated with either $2 \cdot 25 \mu \mathrm{g} / \mathrm{ml}$ mouse anti-human oestrogen receptor (Dako Diagnostics, High Wycombe, Bucks, UK) or $5 \mu \mathrm{g} / \mathrm{ml}$ mouse anti-human progesterone receptor (Affinity BioReagents, Neschanic Station, New Jersey, USA) at $4{ }^{\circ} \mathrm{C}$ overnight. Mouse immunoglobulin $\mathrm{G}(\mathrm{IgG})$ $(5 \mu \mathrm{g} / \mathrm{ml})$ was used for control sections. The next day all incubations were carried out at room temperature and after each incubation the sections were washed twice in 0.01 M PBS for $5 \mathrm{~min}$. The sections were incubated for $30 \mathrm{~min}$ with $100 \mu \mathrm{g} / \mathrm{ml}$ rabbit anti-mouse IgG (Nordic Immunology, Tilburg, The Netherlands), followed by an incubation with $60 \mu \mathrm{g} / \mathrm{ml}$ mouse peroxidase antiperoxidase. The sections were then incubated with

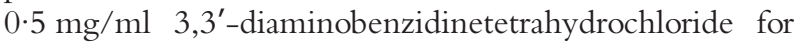
$10 \mathrm{~min}$. The reaction was stopped with distilled water and the sections were dehydrated sequentially in ethanol, xylene and mounted in DPX mountant. The sections were randomly labelled to avoid counting bias and the intensity of the stain determined under a microscope on a scale of 0 (absent) to 4 (very strong).

\section{Statistical analysis}

Values are given as the mean optical density \pm s.E.M. An initial comparison was made between the inseminated cows with no embryo present and the uninseminated control group by $t$-test statistics. Pregnant (PREG) and non-pregnant (NP) values were subsequently compared using unbalanced one-way analysis of variance (ANOVA) with Unistat Statistical package version $4 \cdot 6$. The number of animals expressing detectable levels of oxytocin receptor mRNA was compared using $\chi^{2}$ test.

\section{Results}

There were no significant differences between the inseminated cows with no embryo present and the uninseminated control groups in oxytocin, oestrogen or progesterone receptor expression. Data from these two groups were therefore pooled to form a single nonpregnant (NP) group. Data on the steroid hormone profiles of these cows have been reported previously (Mann et al. 1996) and showed that the luteolytic fall of progesterone or rise in oestradiol had not yet started in either group at the time of tissue collection on day 16 (progesterone: PREG $7 \cdot 3 \pm 0.6 \mathrm{ng} / \mathrm{ml}$ vs NP $6.3 \pm 0.5 \mathrm{ng} / \mathrm{ml}$; oestradiol: PREG $0.7 \pm 0.1 \mathrm{pg} / \mathrm{ml}$ vs NP $1 \cdot 0 \pm 0 \cdot 1 \mathrm{pg} / \mathrm{ml})(P>0 \cdot 05)$.

\section{The expression of oxytocin receptor in the day 16 bovine uterus}

Very low levels of oxytocin receptor mRNA were observed in the inner ring of the myometrium of both the PREG and NP groups (OD values $0 \cdot 013 \pm 0 \cdot 001 \quad(n=15)$ and $0 \cdot 016 \pm 0 \cdot 002(n=14)$ respectively) (Fig. 1A). In one inseminated non-pregnant and one control cow, there was strong expression of oxytocin receptor mRNA in the LE. Another inseminated non-pregnant and three control cows showed lower expression of oxytocin receptor mRNA in the LE. The mean OD value for OTR mRNA expression in these 6 cows was $0 \cdot 04 \pm 0 \cdot 02$, whereas for the remaining $8 \mathrm{NP}$ cows the OD was $<0 \cdot 01$ (Fig. 1A,E). Conversely, no oxytocin receptor mRNA expression was detected in the endometrium of any of the PREG cows (OD value $<0.01 \quad(n=15)$; this was significantly different from the NP group, $P<0 \cdot 025, \chi^{2}$ test) (Fig. $1 \mathrm{C}$ ). The two NP cows with the strongest expression of oxytocin receptor mRNA also showed strong oxytocin receptor protein expression (Fig. 2A). However, in the endometrium of the NP cows which showed low oxytocin receptor mRNA expression, no ${ }^{125}$ I-OTA binding was observed.

\section{The PGFM response to oxytocin}

The basal level of plasma PGFM production before the oxytocin challenge was similar in both the pregnant and non-pregnant groups. Results of the challenge in the pregnant cows has been reported previously (Mann et al. 1996). The mean oxytocin response in the NP group (expressed as the percentage increase over pre-oxytocin levels) $(187 \% \pm 15 \%)$ was similar to that previously reported on day 16 in cyclic cows $(180 \% \pm 20 \%)$ (Lamming \& Mann 1995), indicative of the development of a luteolytic mechanism. The response in the two cows with measurable oxytocin receptor protein was 310\% and $258 \%$. By comparison, the response in the PREG group was inhibited $(131 \% \pm 11 \% ; P<0 \cdot 01)$, demonstrating a positive effect of the presence of an embryo. It should be noted that a large dose of oxytocin was used and that very few oxytocin receptors are required to elucidate a PGFM response. It is likely that this level of oxytocin receptor expression is below the detection limit of the in situ hybridisation assay. 

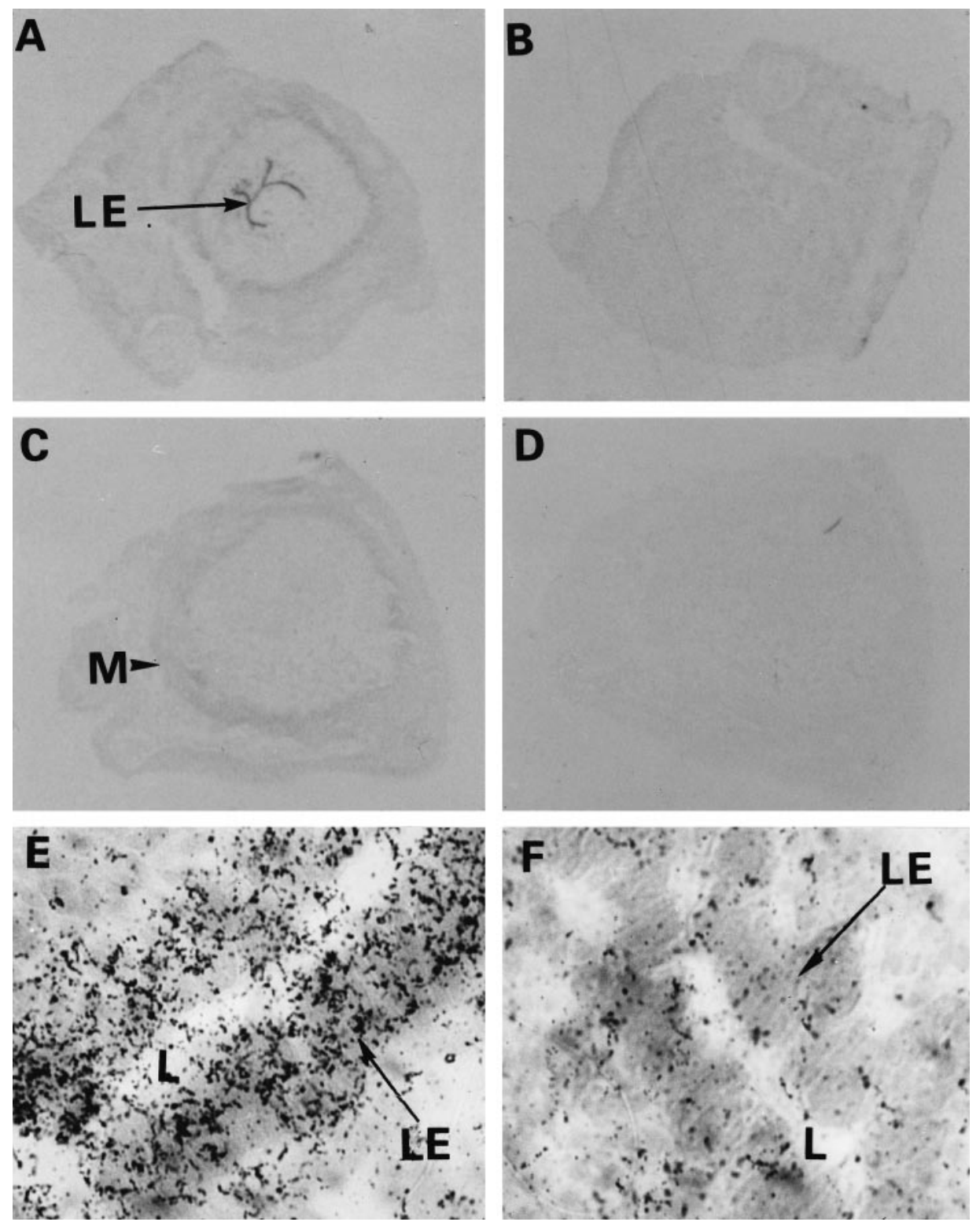

Figure 1 In situ hybridisation showing the expression of OTR mRNA in the bovine uterus on day 16 . Sections were probed with either antisense ( $A, C$ and $E$ ) or sense (B, D and F) oligonucleotides. (A) Uterine horn cross section from a day $16 \mathrm{NP}$ cow showing moderately strong expression of OTR mRNA in the luminal epithelium (LE). The corresponding sense section (B) was blank. (C) A typical pregnant day 16 uterine horn cross section showing no observable OTR mRNA expression in the endometrium, but it was expressed in the inner ring of the myometrium (M). The corresponding sense section is shown in (D). (E) Section of uterine horn from a day 16 NP cow coated with photographic emulsion and counterstained with haematoxylin and eosin. The silver grains clearly show that the OTR mRNA was localised to the LE. The uterine lumen is labelled (L). The corresponding sense section is shown in (F). Magnification $\times 3$ in $A, B, C$ and $D ; \times 1300$ in $E$ and $F$.

The expression of oestrogen receptor in the day 16 bovine uterus

In the NP group, there was moderate oestrogen receptor mRNA expression in the deep glands (DG) next to the myometrium. The expression of oestrogen receptor mRNA in the luminal epithelium was low to moderate. The oestrogen receptor mRNA levels in the superficial glands (SG) were similar to those observed in the LE (Figs 3A,E and 4A). Oestrogen receptor mRNA was also 

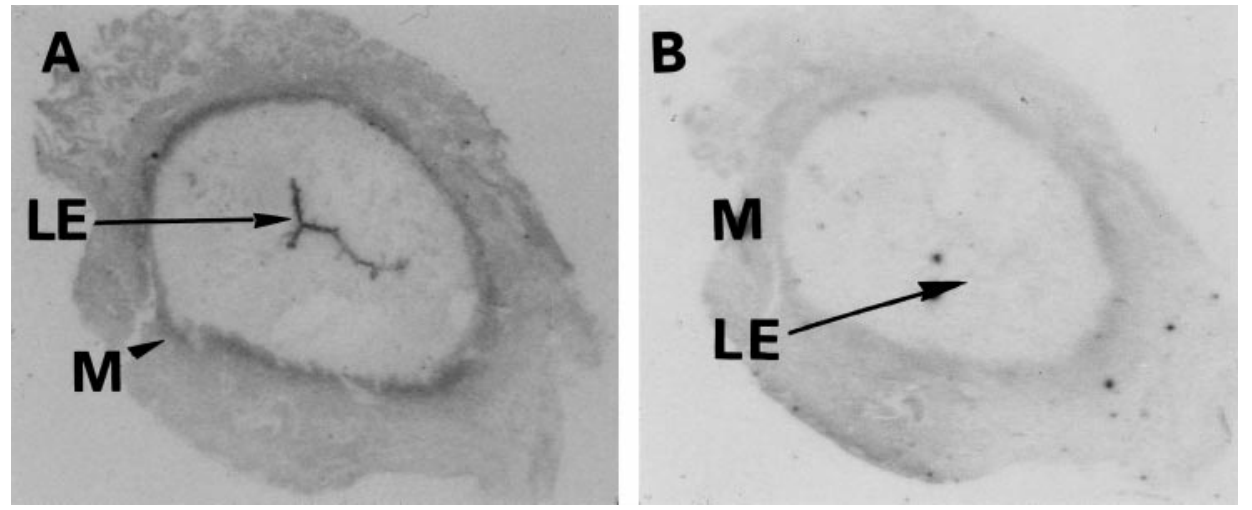

Figure 2 Autoradiographical location of OTR using ${ }^{125}$ I-OTA. Sections were treated with either excess unlabelled oxytocin (non-specific binding, NSB) or without (total binding, TB). (A) TB and (B) NSB cross sections of a uterine horn from one of two day 16 non-pregnant cows which showed binding of

${ }^{125} \mathrm{I}$-OTA to the luminal epithelium (LE) and the inner myometrial ring (M). Magnification $\times 3$.

present in the caruncular stroma (CS) at moderate levels, while low levels were detected in the inner ring of the myometrium (Fig. 3A). In the PREG group, oestrogen receptor mRNA was localised to the same regions and at similar concentrations (Figs 3C and 4A). Indeed, there were no significant differences in the expression of oestrogen receptor mRNA in the epithelial cells between the NP and PREG groups (Fig. 4A).

The oestrogen receptor protein was localised using immunocytochemistry (Fig. 5A,B). The pattern of protein localisation was very similar to that of oestrogen receptor mRNA in both the PREG and NP groups (Fig. 5A-D). The slight difference was that oestrogen receptor protein intensity was higher in the LE than in the SG. The overall correlation coefficient for mRNA and protein expression was $r=0.62(P<0.01)$. It was interesting to note that oestrogen receptor showed stronger expression in the LE when it was adjacent to the caruncles in comparison with the intercaruncular endometrium. Similar observations have been seen in sheep (Wathes \& Hamon 1993). Again, there was no significant difference in the expression of oestrogen receptor protein between the NP and PREG groups in the epithelial cell types (Fig. 4B). These results show that pregnancy had no effect on oestrogen receptor expression in the cow on day 16. Furthermore, in the NP cows, there was no difference in the level of oestrogen receptor mRNA in the luminal epithelium between the six cows expressing oxytocin receptor mRNA and the eight cows which did not (OD values, $0.06 \pm 0.01$ vs $0 \cdot 07 \pm 0 \cdot 01$ respectively; $P>0 \cdot 1)$.

\section{The expression of progesterone receptor in the day 16 bovine uterus}

The strongest expression of progesterone receptor mRNA was in the caruncular stroma with similar concentrations in both the PREG and NP groups (Figs 6A,C and 7).
Progesterone receptor mRNA was also expressed in the subepithelial stroma underlying the luminal epithelium and superficial glands although at low, but similar levels in both PREG and NP groups (Figs 6A,C and 7). Progesterone receptor mRNA expression in the deep glands was at the limit of detection, with variable results between animals. It was present in 8 out of 15 PREG animals but was found in this location in only 2 out of 12 NP animals (Fig. 6A,C). Progesterone receptor mRNA expression was stronger in the inner ring of myometrium than in the outer ring (Fig. 6A,C).

There was specific nuclear staining in the stroma and myometrium with the presence of an embryo having no effect on progesterone receptor protein expression in these regions. Progesterone receptor was also detectable in the deep glands, although its expression was variable with detectable levels being observed in 8 out of 15 PREG animals and only 3 out of 14 NP animals (Fig. 8C). There was specific immunostaining with the progesterone receptor antibody along the apical luminal epithelium, but no nuclear localisation was observed in the luminal epithelium at this stage of the cycle. This staining was similar in both the non-pregnant and pregnant groups (Fig. 8A,B). No staining was observed in the subepithelial stroma or caruncular stroma, despite detectable concentrations of progesterone receptor mRNA being present in these regions.

\section{Discussion}

The results from this paper show that oxytocin receptor mRNA was detectable in the luminal epithelium of nearly half the non-pregnant cows, but none of the pregnant cows on day 16. This increase in oxytocin receptor expression was associated with an increased responsiveness of the non-pregnant cows to an oxytocin challenge in 

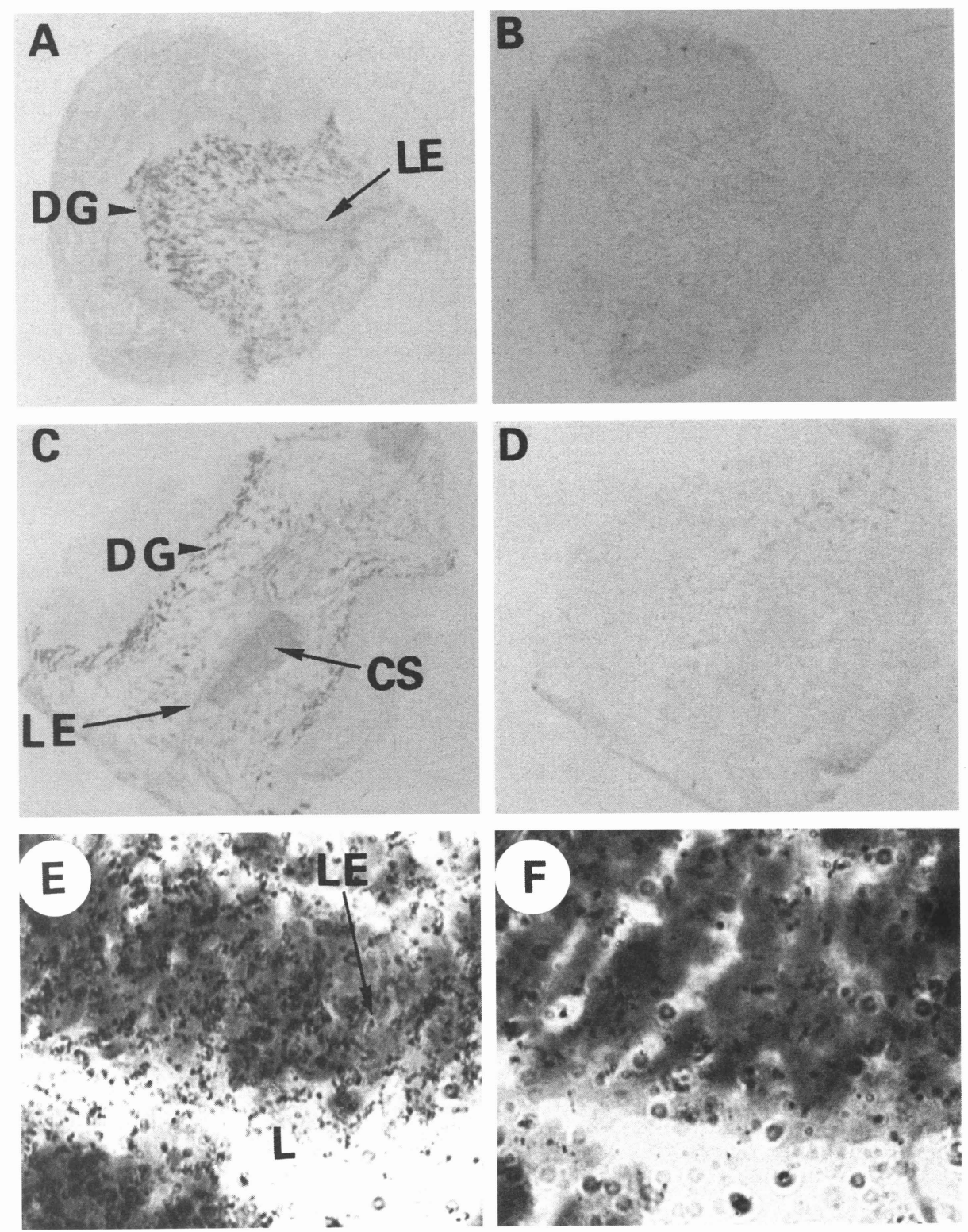

Figure 3 In situ hybridisation showing the expression of ER mRNA in the bovine uterus on day 16. Sections were probed with either antisense (A, C and E) or sense (B, D and F) ER oligonucleotides. (A) Uterine horn cross section from a day 16 non-pregnant (NP) cow showing moderate expression of ER mRNA in the luminal epithelium (LE) and higher expression in the deep glands (DG). The corresponding sense section (B) was blank. (C) Typical pregnant day 16 uterine horn cross section with similar expression of ER mRNA both in quantity and location to the NP group. There was also moderate expression of ER mRNA in the caruncular stroma (CS). The corresponding sense section is shown in (D). (E) Section of uterine horn from a day 16 NP cow coated with photographic emulsion and counterstained with haematoxylin and eosin. The silver grains clearly show that the ER mRNA was localised to the LE. The uterine lumen is labelled (L). The corresponding sense section is shown in (F). Magnification $\times 3$ in A, B, C and D; $\times 1300$ in E and F.

terms of PGFM release. These results confirm that the animals were sampled at the onset of luteolysis, but before the progesterone levels in the non-pregnant and pregnant animals diverged (Mann et al. 1996). This increase in oxytocin receptor expression was not associated with any changes in the pattern or concentrations of oestrogen receptors in the endometrium compared with the pregnant animals.

Downloaded from Bioscientifica.com at 04/26/2023 12:41:53PM 

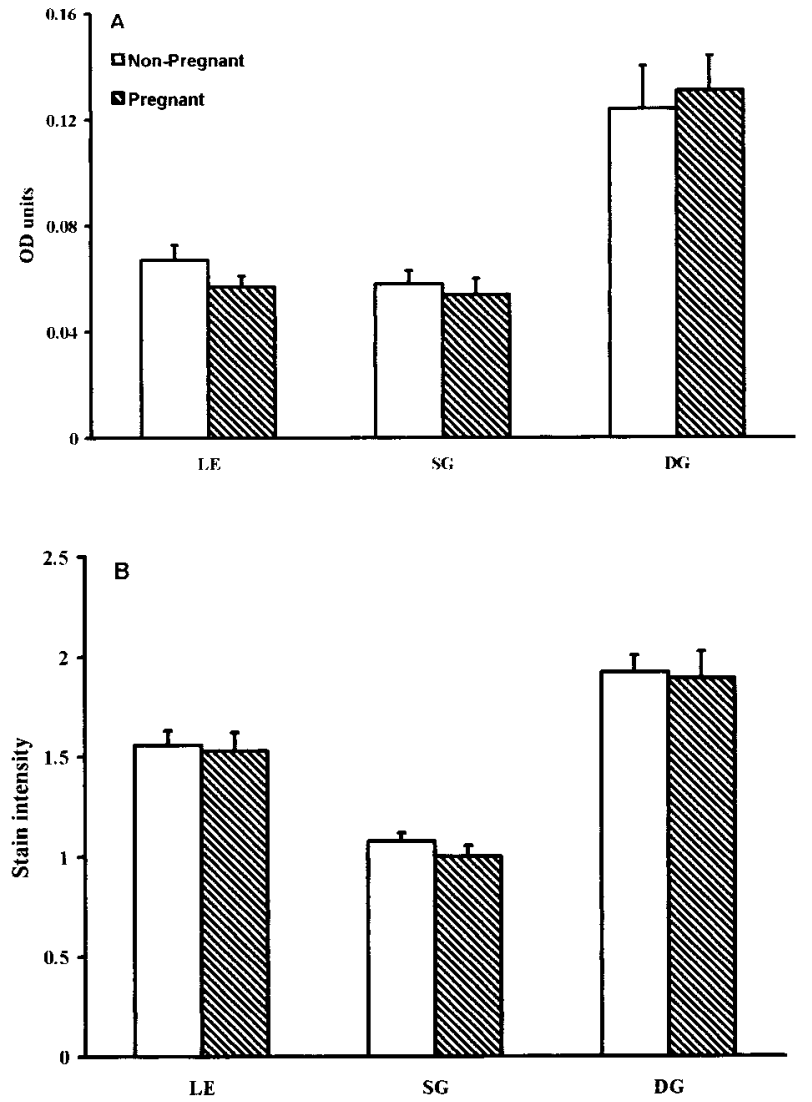

Figure 4 (A) The expression of ER mRNA in the bovine uterus on day 16 measured as OD units from the autoradiographs. The values are mean OD \pm S.E.M. of PREG (hatched bars; $n=15$ ) and NP (open bars; $n=14$ ) cows. In both the PREG and NP groups, expression of ER mRNA was significantly higher in the deep glands (DG) than in the luminal epithelium (LE) and superficial glands (SG) $(P<0 \cdot 01)$. There were no significant differences between the pregnant and non-pregnant groups. (B) The localisation of ER protein in the bovine uterus on day 16 , measured as the intensity of the stain ranging from 0 (absent) to 4 (very strong) from immunocytochemistry slides. The values are mean intensity \pm S.E.M. of the PREG (hatched bars; $n=15$ ) and NP (open bars; $n=14$ ) cows. The pattern of localisation of the ER protein was exactly the same as for ER mRNA and again there were no differences between the pregnant and non-pregnant groups.

The fact that oxytocin receptor mRNA appeared initially in the luminal epithelium on day 16 in the non-pregnant cows is comparable to the sheep, in which it was first detectable on day 14. Those cows which did not yet express oxytocin receptor would be likely to experience a slightly longer cycle; the oestrous cycle length in cows normally varies between 18 and 24 days. Only the non-pregnant cows with the strongest oxytocin receptor mRNA expression showed observable oxytocin antagonist binding. This implied that there was a slight temporal delay in the translation of the mRNA into protein. The timing is consistent with a previous study in the cow using radioreceptor assays in which the rise in oxytocin receptors was reported to occur on day 15 (Jenner et al. 1991). Furthermore, injection of oxytocin to non-pregnant cows failed to release $\mathrm{PGF}_{2 \alpha}$ on day 15 , but did so on day 17 (Lamming \& Mann 1995). Development of oxytocin receptors on the luminal epithelium alone is probably sufficient to elicit a full luteolytic response in terms of $\mathrm{PGF}_{2 \alpha}$ secretion in both cattle and sheep (Wathes \& Lamming 1995), although receptor concentrations will increase further at oestrus as the corpus luteum regresses and oestrogen levels rise (Stevenson et al. 1994). This was supported by the fact that the oxytocin receptor was confined solely to the luminal epithelium, but still elicited a positive PGFM response to oxytocin.

In comparison, no oxytocin receptor mRNA was detected in the pregnant endometrium on day 16. A significant difference in the endometrial oxytocin binding between pregnant and non-pregnant cows has previously been reported on day 17 (Fuchs et al. 1990). The presence of an embryo presumably suppressed oxytocin receptor expression by the actions of IFN $\tau$. This was shown to be present in the uterine flushings of pregnant animals using an antiviral assay (GE Mann \& G E Lamming, unpublished observations). IFN $\tau$ is known to bind to the type 1 interferon receptor present in the endometrium around luteolysis (Godkin et al. 1984).

Two questions currently of interest concerning oxytocin receptor regulation are first, whether oestradiol, acting through its receptor, plays an essential role in the up-regulation of oxytocin receptors preceding luteolysis and secondly, whether suppression of oestradiol receptor development is a key component of the inhibitory action of IFN $\tau$. Previous studies have shown that, on day 16, the luteolytic fall in progesterone or rise in follicular oestradiol has not yet commenced (Mann et al. 1996). This would suggest that the increase in oxytocin receptor mRNA expression seen in the non-pregnant endometrium was not caused by an increase in oestradiol or decline in progesterone levels.

In the ewe, there are several lines of evidence to suggest that oestradiol is not essential for the initial development of oxytocin receptors in the luminal epithelium, although it may assist the spread of receptors to other cell types once luteolysis has been initiated. The oxytocin receptor up-regulation in the luminal epithelium occurs before any detectable change in oestrogen receptor concentrations (Wathes \& Hamon 1993). Oxytocin receptors are present in the luminal epithelium of ovariectomised ewes (Wathes et al. 1996b) and also develop spontaneously in explants of endometrial tissue collected from luteal phase ewes and cows in the absence of any added steroid (Sheldrick \& Flick-Smith 1993, Horn et al. 1998). Both of these findings suggest that oxytocin receptor synthesis does not require steroids and that they may be constitutively expressed in the epithelial cells (Ivell et al. 1995, Wathes et al. 1996a). 

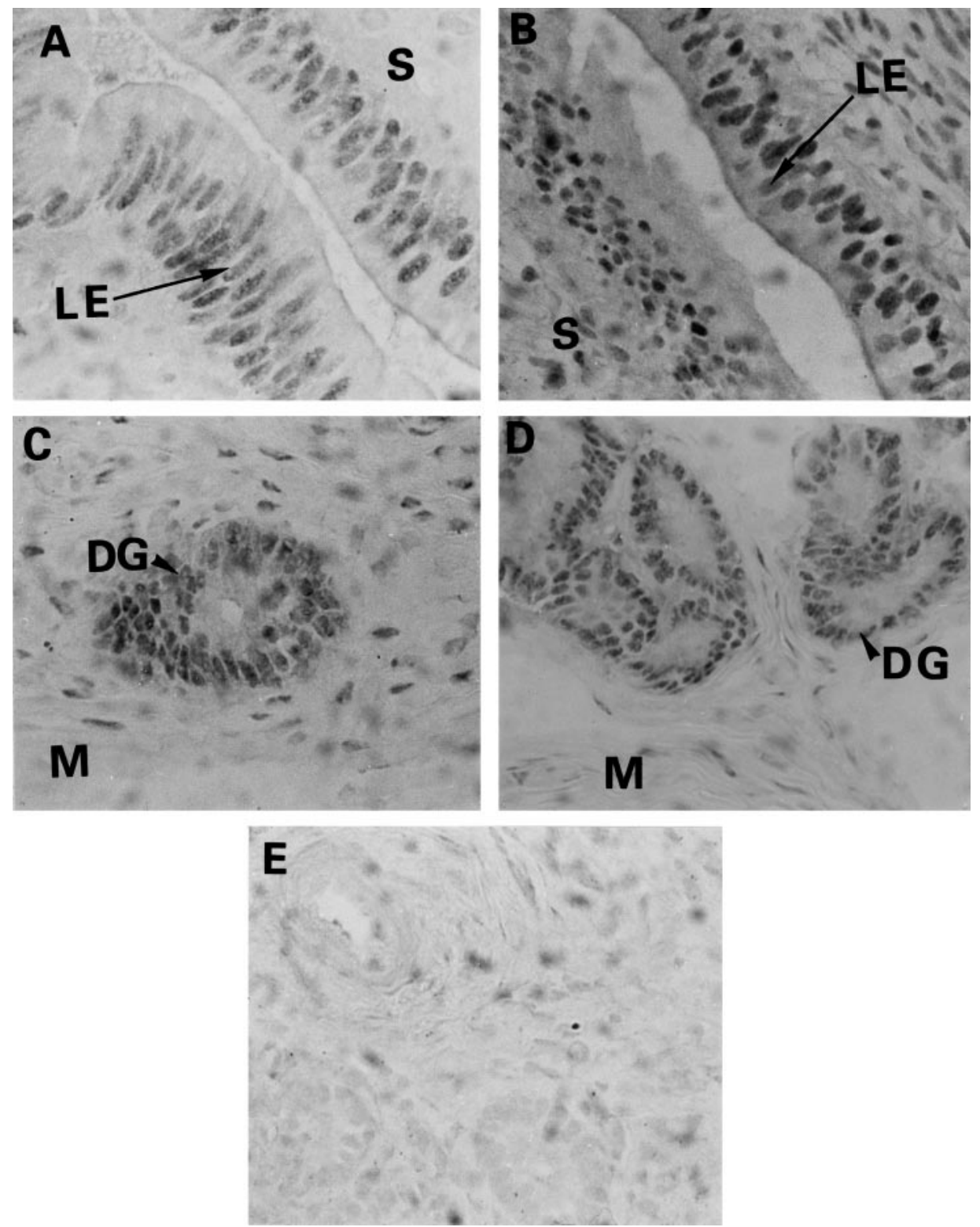

Figure 5 Sections of bovine uterus on day 16 immunostained with ER antibody. In all cases the stain was localised specifically to the nucleus. (A) Localisation of ER in the luminal epithelium (LE) of a non-pregnant cow, while (B) shows the localisation of ER from a pregnant cow. The stroma is labelled (S). The intensity of the stain was similar in both groups. ER localisation in the deep glands (DG) is shown in (C) from a non-pregnant animal and (D) from a pregnant animal. The myometrium is labelled (M). Again the stain intensity was similar in both groups. (E) Corresponding control section to (C) immunostained with mouse IgG showing the specificity of the ER antibody. Magnification $\times 1300$.

Our results have shown that in the non-pregnant cows on day 16, the oestrogen receptor mRNA and protein were expressed at moderate levels in deep glands and low to moderate levels in the luminal epithelium and superficial glands. This is consistent with a previous study in the cow which found a temporal and cell type difference in the expression of the oestrogen receptor (Boos et al. 1996,
Robinson et al. 1998). There was a low level in the luminal epithelium throughout the cycle with peaks on days 1 and 15. In contrast, the glandular epithelium and stroma oestrogen receptor expression was maximal at oestrus, when circulating oestradiol levels were high. Thus, it was concluded that oestrogen promotes uterine oestrogen receptor synthesis in most cell types, except in 

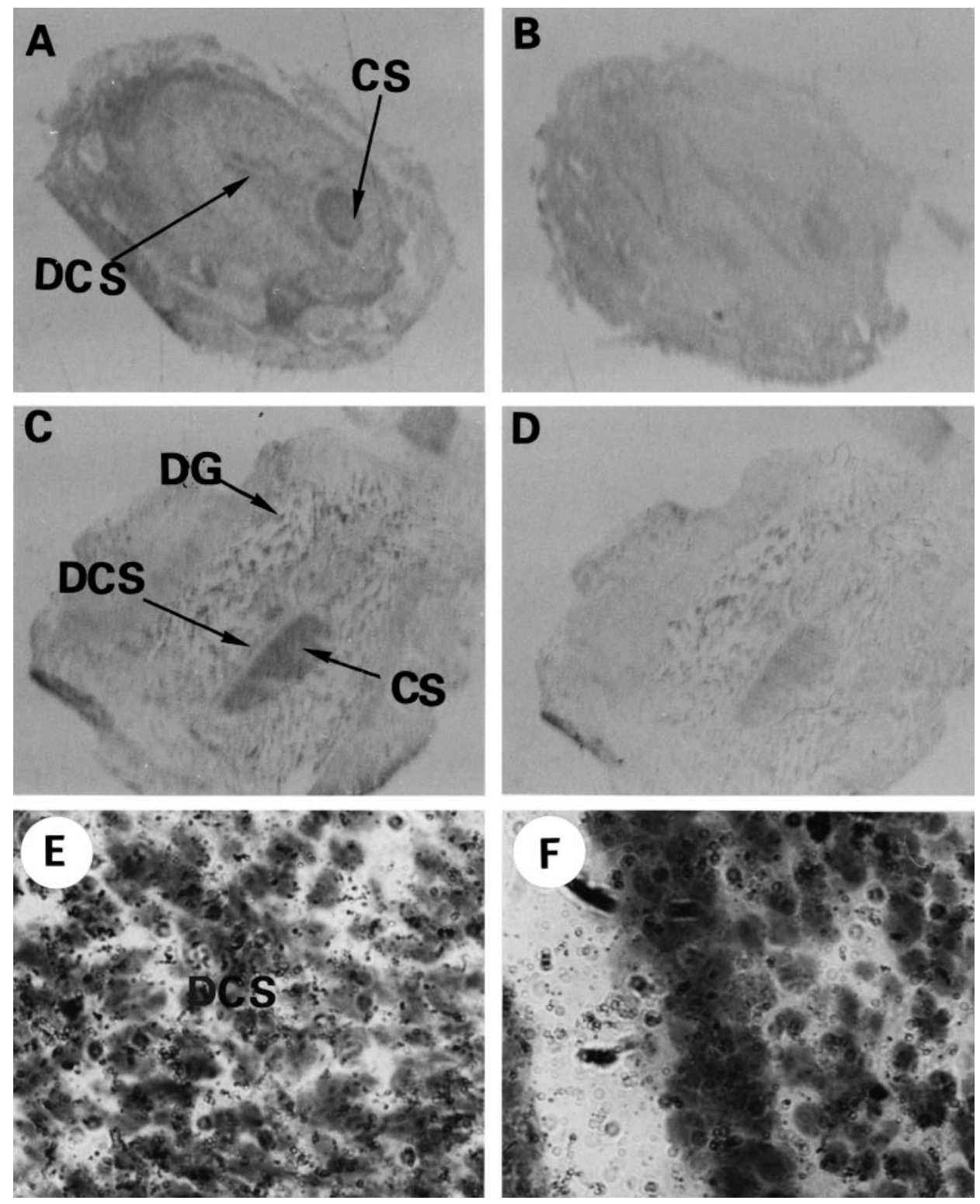

Figure 6 In situ hybridisation showing the expression of PR mRNA in the bovine uterus on day 16. Sections were probed with either antisense $(A, C$ and $E)$ or sense $(B, D$ and $F)$ PR oligonucleotides. (A) Uterine horn cross section from a day $16 \mathrm{NP}$ cow with moderate expression of PR mRNA in the caruncular stroma (CS) and low expression in the dense caruncular-like stroma (DCS) and superficial glands. The corresponding sense section (B) was blank. (C) Typical PREG day 16 uterine horn cross section with similar expression of PR mRNA both in quantity and location to the NP group. The deep glands are labelled (DG). (E) Section of uterine horn from a day 16 PREG cow coated with photographic emulsion and counterstained with haematoxylin and eosin. The silver grains clearly show that the PR mRNA was localised to the DCS. The corresponding sense section is shown in (F). Magnification $\times 3$ in $\mathrm{A}, \mathrm{B}, \mathrm{C}$ and $\mathrm{D} ; \times 1300$ in $\mathrm{E}$ and $\mathrm{F}$.

the luminal epithelium, which appeared not to be strongly influenced by ovarian steroid hormones (Boos et al. 1996). In sheep, conversely, oestrogen receptor levels were low throughout the luteal phase, except in the deep glands (Wathes \& Hamon 1993, Spencer \& Bazer 1995). There- fore, there is apparently a greater suppression of oestrogen receptor during the luteal phase in sheep compared with cows. In cows, it would appear that, in the luminal epithelium, oestrogen and oxytocin receptors have different temporal regulation throughout the cycle. 


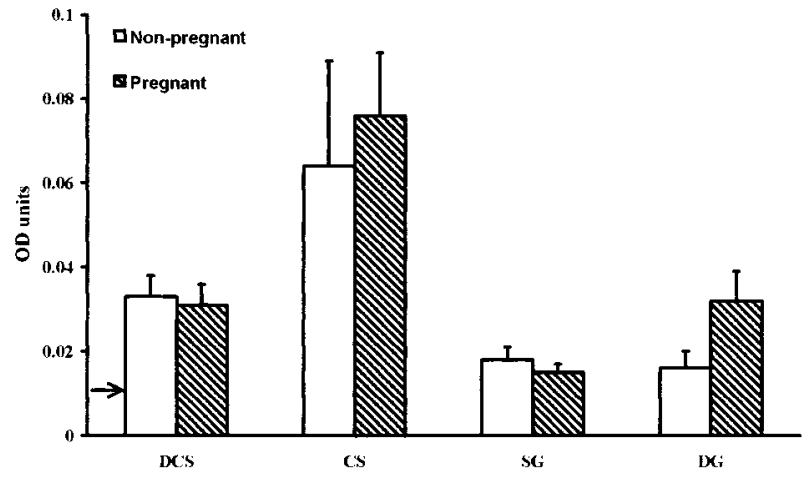

Figure 7 The expression of PR mRNA in the bovine uterus on day 16 measured as OD units from autoradiographs. The values are mean OD \pm S.E.M. of PREG (hatched bars; $n=15$ ) and NP (open bars; $n=12$ ) cows. In both the PREG and NP groups, there was similar expression of PR mRNA in the caruncular stroma (CS). There was lower expression of PR mRNA in the dense caruncular-like stroma (DCS), superficial glands (SG) and deep glands (DG) in both the PREG and NP cows. The arrow on the $y$-axis indicates the detection limit (OD value $=0 \cdot 01$ ).

It has been hypothesised that, in sheep, the inhibitory action of IFN $\tau$ on oxytocin receptor up-regulation is achieved by inhibiting a preceding up-regulation of oestrogen receptors (Bazer et al. 1997). This is supported by: (i) the decreased expression of oestrogen receptors in the pregnant horn of unilaterally pregnant ewes (Lamming et al. 1995); (ii) the ability of intrauterine infusion of roIFN $\tau$ during the luteal phase to inhibit oestrogen and oxytocin receptor expression, but not progesterone receptor concentrations (Spencer et al. 1995a); (iii) the demonstration that roIFN $\tau$ prevented the up-regulation of oestrogen receptor mRNA and protein as well as oxytocin receptor expression in response to an exogenous oestradiol injection on day 12 (Spencer et al. 1995b). In contrast, our results show that, in cows, the presence of an embryo caused no significant suppression of oestrogen receptor expression in the luminal epithelium, superficial glands or deep glands on day 16.

In sheep and cows, progesterone receptor mRNA and protein concentrations were absent or very low in epithelial cells of both pregnant and non-pregnant animals around the time of luteolysis, but were moderately expressed in the caruncular stroma (Wathes \& Hamon 1993, Spencer \& Bazer 1995, Boos et al. 1996). We obtained similar results for progesterone receptor mRNA expression on day 16, with moderate levels in the caruncular stroma and very low levels in the superficial glands and some deep glands. In our study, the expression of progesterone receptor protein on day 16 was confined to the stroma, myometrium and in some animals to the deep glands. Progesterone receptor protein was, however, absent from the caruncular stroma which had expressed moderate levels of progesterone receptor mRNA. This would suggest that in certain cell types, including the
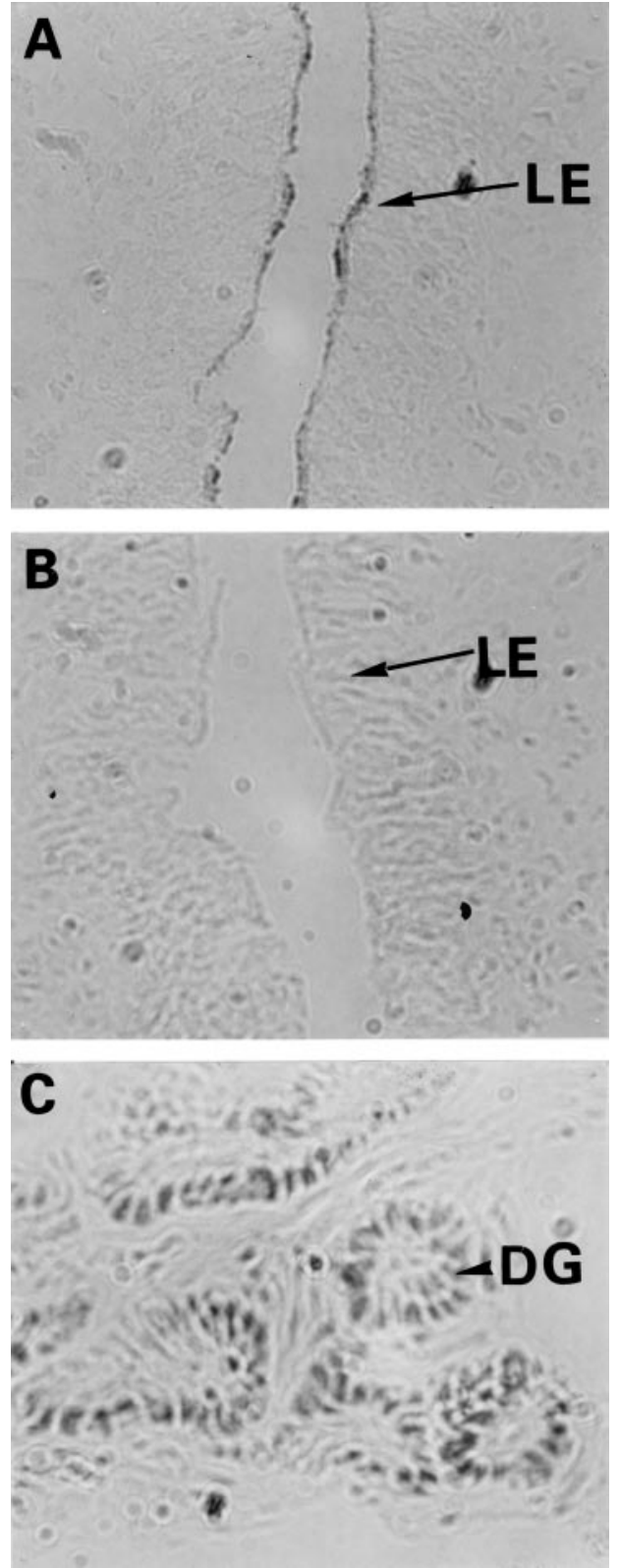

Figure 8 Sections of bovine uterus on day 16 immunostained with PR antibody. (A) Shows the localisation of PR along the apical luminal epithelium (LE) of a non-pregnant cow. (B) Shows the corresponding control sections immunostained with mouse IgG, showing the specificity of the PR antibody. Specific nuclear PR expression in the deep glands (DG) is shown in (C) from a day 16 pregnant animal. Magnification $\times 1300$.

caruncular stroma, progesterone receptor protein expression was inhibited post-transcriptionally. There was no difference in progesterone receptor expression between pregnant and non-pregnant cows, therefore differences in oxytocin receptor expression between these groups 
are not attributable to previous progesterone receptor down-regulation in the non-pregnant animals.

In conclusion, oxytocin receptor mRNA expression was up-regulated in some of the non-pregnant cows on day 16 and this was associated with the ability of the cows to respond to an oxytocin challenge by releasing $\mathrm{PGF}_{2 \alpha}$. Both the $\mathrm{PGF}_{2 \alpha}$ release and oxytocin receptor mRNA expression were suppressed by the presence of an embryo. The embryo had no effect on the expression pattern or concentration of oestrogen or progesterone receptor mRNA and protein, and thus inhibition of oxytocin receptor in cows did not appear to involve either a previous decrease in uterine oestrogen receptor expression or maintenance of progesterone receptor expression.

\section{Acknowledgements}

The authors wish to thank all the animal technicians at Sutton Bonnington for the care of the animals and their help in the collection of the tissues. We would like to thank Mrs Barbara Wilsmore for the preparation of the photographs and the Ministry of Agriculture, Fisheries and Food and the Milk Development Council for financial support.

\section{References}

Ayad VJ, Matthews EL, Wathes DC, Parkinson TL \& Wild Ml 1991 Autoradiographical localization of oxytocin receptors in the endometrium during the oestrous cycle of the ewe. Journal of Endocrinology 130 199-206.

Bathgate R, Rust W, Balvers M, Hartung S, Morley S \& Ivell R 1995 Structure and expression of the bovine oxytocin receptor gene. DNA and Cell Biology 14 1037-1048.

Bazer FW 1989 Establishment of pregnancy in pigs and sheep. Reproduction, Fertility and Development 1 237-242.

Bazer FW, Spencer TE \& Ott TL 1997 Interferon tau: a novel pregnancy recognition signal. American Journal of Reproductive Immunology 37 414-420.

Beard A, Hunter MG \& Lamming GE 1994 Quantitative control of oxytocin-induced $\mathrm{PGF}_{2 \alpha}$ release by progesterone and oestradiol. Journal of Reproduction and Fertility 100 143-150.

Boos A, Meyer W, Schwarz R \& Grunert E 1996 Immunohistochemical assessment of oestrogen and progesterone receptor distribution in biopsy samples of the bovine endometrium collected throughout the oestrous cycle. Animal Reproduction Science 44 11-21.

Cherny RA, Salamonsen LA \& Findlay JK 1991 Immunocytochemical localization of oestrogen receptors in the endometrium of the ewe. Reproduction, Fertility and Development 3 321-331.

Farin CE, Imakawa K, Hansen TR, McDonnell JJ, Murphy CN, Farin PW \& Roberts RM 1990 Expression of trophoblastic interferon genes in sheep and cattle. Biology of Reproduction $\mathbf{4 3}$ 210-218.

Flint APF \& Sheldrick EL 1983 Evidence for a systemic role for ovarian oxytocin in luteal regression in sheep. Journal of Reproduction and Fertility $67215-225$.

Fuchs A-R, Behrens O, Helmer H, Liu C-H, Barros CM \& Fields LJ 1990 Oxytocin and vasopressin receptor in bovine endometrium and myometrium during the oestrous cycle and early pregnancy. Endocrinology 127 629-636.
Godkin JD, Bazer FW \& Roberts RM 1984 Ovine trophoblast protein-1, an early secreted blastocyst protein, binds specifically to uterine endometrium and affects protein synthesis. Endocrinology 114 120-130.

Haresign W, Foster JP, Haynes NB, Crighton DB \& Lamming GE 1975 Progesterone levels following treatment of seasonally anoestrus ewes with synthetic LH-releasing hormone. Journal of Reproduction and Fertility 43 269-279.

Hixon JE \& Flint APF 1987 Effects of luteolytic dose of oestradiol benzoate on uterine oxytocin receptor concentrations, phosphoinositide turnover and prostaglandin $\mathrm{F}_{2 \alpha}$ secretion in sheep. Journal of Reproduction and Fertility 79 457-467.

Horn S, Bathgate R, Lioutas C, Bracken K \& Ivell R 1998 Bovine endometrial epithelial cells as a model system to study oxytocin receptor regulation. Human Reproduction Supplement (In Press).

Ing NH \& Tornesi MB 1997 Estradiol up-regulates estrogen receptor and progesterone gene expression in specific ovine uterine cells. Biology of Reproduction 56 1205-1215.

Ivell R, Rust W, Einspanier A, Hartung S, Fields M \& Fuchs A-R 1995 Oxytocin and oxytocin receptor gene expression in the reproductive tract of pregnant cow: rescue of luteal oxytocin production at term. Biology of Reproduction 53 553-560.

Jenner LJ, Parkinson TJ \& Lamming GE 1991 Uterine oxytocin receptor in cyclic and pregnant cows. Journal of Reproduction and Fertility 91 49-58.

Kaker ML, Murray RD \& Dobson H 1984 Plasma hormone changes in cows during induced or spontaneous calving and the early postpartum period. Veterinary Record 115 378-382.

Lamming GE \& Mann GE 1995 Control of endometrial oxytocin receptors and prostaglandin $\mathrm{F}_{2 \alpha}$ production in cows by progesterone and oestradiol. Journal of Reproduction and Fertility 103 69-73.

Lamming GE, Wathes DC, Flint APF, Payne JH, Stevenson KR \& Vallet JL 1995 Local actions of trophoblast interferons in suppression of the development of oxytocin and oestradiol receptors in ovine endometrium. Journal of Reproduction and Fertility 105 165-175.

McCracken JA, Scrhamm W \& Okulicz W 1984 Hormone receptor control of pulsatile secretion of $\mathrm{PGF}_{2 \alpha}$ from the ovine uterus during luteolysis and abrogation in early pregnancy. Animal Reproduction Science 7 31-55.

Madigou T, Tiffoche C, Le Gal F, Pelletier J \& Thieulant M 1995 Embase sequence Z66555.

Madigou T, Tiffoche C, Lazennec G, Pelletier J \& Thieulant M 1996 The sheep estrogen receptor: cloning and regulation of expression in the hypothalamus-pituitary axis. Molecular and Cellular Endocrinology 121 153-163.

Mann GE \& Lamming GE 1994 Use of repeated biopsies to monitor endometrial oxytocin receptors in cows. Veterinary Record 135 403-405.

Mann GE, Lamming GE \& Fray MD 1995 Plasma oestradiol during early pregnancy in the cow and the effect of treatment with buserelin. Animal Reproduction Science 37 121-131.

Mann GE, Mann SJ \& Lamming GE 1996 The inter relationship between the maternal hormone environment and the embryo during the early stages of pregnancy in the cow. Journal of Reproduction and Fertility Abstract Series 1755.

Peters AR 1996 Embryo mortality in the cow. Animal Breeding Abstracts 64 587-598.

Robinson RS, Mann GE, Lamming GE \& Wathes DC 1998 Oxytocin, oestrogen and progesterone receptor mRNA expression in the bovine endometrium throughout the oestrous cycle. Journal of Reproduction and Fertility Abstract Series 2197.

Sheldrick EL \& Flick-Smith HC 1993 Effect of ovarian hormones on oxytocin receptor concentrations in explants of uterus from ovariectomised ewes. Journal of Reproduction and Fertility $\mathbf{9 7}$ 241-245. 
Silvia WJ \& Raw RE 1993 Activity of phospholipase C and release of prostaglandin $\mathrm{F}_{2 \alpha}$ by endometrial tissue from ewes during the oestrous cycle and early pregnancy. Journal of Reproduction and Fertility 97 529-537.

Spencer TE \& Bazer FW 1995 Temporal and spatial alterations in uterine estrogen receptor and progesterone receptor gene expression during the estrous cycle and early pregnancy. Biology of Reproduction 53 1527-1543.

Spencer TE, Ing NH, Ott TL, Mayes JS, Becker WC, Watson GH, Mirando MA \& Bazer FW 1995a Intrauterine injections of ovine interferon- $\tau$ alters oestrogen receptor and oxytocin receptor expression in the endometrium of cyclic ewes. Journal of Molecular Endocrinology 15 203-220.

Spencer TE, Becker WC, George P, Mirando MA, Ogle TF \& Bazer FW $1995 b$ Ovine interferon- $\tau$ inhibits estrogen receptor up-regulation and estrogen-induced luteolysis in cyclic ewes. Endocrinology 136 4932-4944.

Stevenson KR, Riley PR, Stewart HJ, Flint APF \& Wathes DC 1994 Localization of oxytocin receptor mRNA in the ovine uterus during the oestrous cycle and early pregnancy. Journal of Molecular Endocrinology 12 93-105.

Vallet JL, Lamming GE \& Batten M 1990 Control of the endometrial oxytocin receptors and uterine response to oxytocin by progesterone and oestradiol in the ewe. Journal of Reproduction and Fertility 90 625-634.
Wathes DC \& Denning-Kendall PA 1992 Control of synthesis and secretion of ovarian oxytocin in ruminants. Journal of Reproduction and Fertility Supplement 45 39-52.

Wathes DC \& Hamon M 1993 Localisation of oestradiol, progesterone and oxytocin receptors in the uterus during the oestrous cycle and early pregnancy of the ewe. Journal of Endocrinology 138 479-491.

Wathes DC \& Lamming GE 1995 The oxytocin receptor, luteolysis and the maintenance of pregnancy. Journal of Reproduction and Fertility Supplement 49 53-67.

Wathes DC, Flick-Smith H, Leung ST, Stevenson KR, Meier S \& Jenkin G 1996a Oxytocin receptor development in the ovine uterus and cervix throughout pregnancy and at parturition as determined by in situ hybridization analysis. Journal of Reproduction and Fertility $10625-31$.

Wathes DC, Mann GE, Payne JH, Riley PR, Stevenson KR \& Lamming GE $1996 b$ The regulation of oxytocin, oestradiol and progesterone receptor in different uterine regions by oestradiol, progesterone and oxytocin in ovariectomized ewes. Journal of Endocrinology 151 375-393.

Received 18 February 1998

Revised manuscript received 16 July 1998

Accepted 25 August 1998 